\title{
Dakwah dalam Bingkai Politik
}

\author{
Hamzah Khaeriyah \\ Sekolah Tinggi Agama Islam Negeri (STAIN) Sorong Papua Barat \\ hamahkhaeriyah@yahoo.co.id
}

Abstract: In the condition of being Indonesia context, the relationship between preaching and politic could be seen in three views. Firstly, accommodative group stated that spiritual life is arranged by religion and secular life is arranged by secular logic. So that, these are necessary attempt to separate between preaching and politic. Secondly, moderate group gives opinion that Islam is not only to understand as a religion but as an ideology. Islam is totalistic religion (kaffah) that arranges all life aspects of society including in social-politic life. Thirdly, idealist-radical groups stated that Islam is there on all ideologies, so that to sacrifice is required the hardness ways and concurrently refused ideology of five principles as the one and only foundation as society organization of social life and that religion must be as ideology to change the five principles of Indonesia. In perspective of al-Quran, politic wished to be preaching philosophy as a reference, having the positive goal so that allow becoming politic as preaching media. Preaching through politic wished can arrange the society with the base of behavior of al-karimah, to unite the society with attitude brotherhood and affection. Be able to uphold the justice, wellbeing and mutual assistance. To uphold the leadership serves to community necessity, arranging the society with the fair law and beneficial progression. Thus, be able to understand that preaching in politic frame should apply on the underlayment of morality and to pay attention of politic ethic.

Keywords: Preaching, Politic, Media, Leadership, Ethic. 


\section{Pendahuluan}

Dakwah Islamiah merupakan aktualisasi teologis yang dimanifestasikan dalam sistem kehidupan masyarakat yang secara teratur dan cara-cara tertentu untuk mempengaruhi rasa, pikir, sikap dan tindakan pada ranah individual dan sosio-kultural dalam rangka mengusahakan terwujudnya ajaran Islam dalam semua segi kehidupan. ${ }^{1}$ Dalam alQur'an Surat an-Nahl ([19]: 125) dijelaskan cara-cara dakwah:

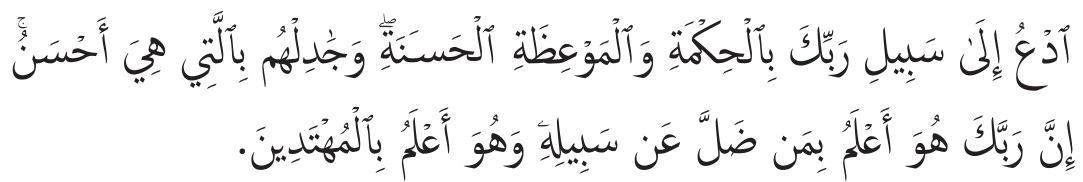

Serulah (manusia) kepada jalan Tuhan-mu dengan hikmah dan pelajaran yang yang baik dan bantahlah mereka dengan cara yang lebih baik. Sesungguhnya Tuhanmu Dialah yang lebih mengetahui tentang siapa yang tersesat dari jalan-Nya dan Dia-lah yang lebih mengetahui orang-orang yang mendapat petunjuk. ${ }^{2}$

Berdasarkan ayat di atas dapat dipahami bahwa dimensi pemaknaan dakwah lebih cenderung pada konsep praktis yang meliputi tabligh keagamaan, propaganda politik, dakwah sebagai aplikasi dari jihad politik, dan dakwah yang meliputi semua aspek kehidupan manusia. ${ }^{3}$ Dalam pelaksanaannya, tugas dakwah ini mirip dengan tugas kerasulan Muhammad Saw. yang berusaha menyebarkan ajaran Islam kepada seluruh umat manusia secara universal, dan membawa misi dakwah untuk memperingatkan dan memanggil manusia ke jalan yang benar. ${ }^{4}$

1 Amrullah Ahmad, Dakwah Islam dan Perubahan Sosial (Yogyakarta: Prima Duta, 1983), 3.

2 Tim Penulis Depag RI, Al-Qur'an al-Karim dan Terjemahnya (Bandung: CV. Diponegoro, 2004), 224.

3 Ahmad Anas, Paradigma Dakwah Kontemporer: Aplikasi Teoritis dan Praktis Solusi Problematika Kekinian (Semarang: PT Pustaka Rizki Putra, 2006), 19.

4 Mohammad Natsir, Fiqhud Da'wah (Jakarta: Media Dakwah, 2000), 125. 
Dakwah Islam juga merupakan sebuah aktivitas komunikasi sehingga keberhasilannya tergantung pada beberapa komponen yang mempengaruhinya, yakni $d a^{\prime} i$ sebagai orang yang menyampaikan pesan (komunikator), mad'u sebagai orang yang menerima pesan (komunikan), materi dakwah sebagai pesan yang akan disampaikan, media dakwah sebagai sarana yang akan dijadikan saluran dakwah, dan metode dakwah sebagai cara yang digunakan untuk berdakwah. Adanya keharmonisan antarunsur tersebut diharapkan tujuan dakwah bisa tercapai secara maksimal. Melihat perkembangan zaman yang semakin pesat dewasa ini, komponen-komponen dakwah tersebut juga dituntut mengikuti perkembangan agar aktivitas dakwah dapat diterima oleh masyarakat sebagai satu elemen tersendiri bagi proses modernisasi. ${ }^{5}$ Dalam pengertian agama, dakwah mengandung arti panggilan dari Tuhan untuk umat manusia agar percaya kepada ajaran Islam dan mewujudkan ajaran yang dipercayainya itu dalam segala segi kehidupannya. Diyakini oleh umat Islam, bahwa tugas Nabi Muhammad adalah mendakwahkan Islam. Dalam konteks itu, kegiatan dakwah dapat mengambil dua bentuk, yakni dakwah struktural dan dakwah kultural. ${ }^{6}$

Dakwah kultural adalah dakwah yang dilakukan dengan cara mengikuti budaya-budaya kultur masyarakat setempat dengan tujuan agar dakwahnya dapat diterima di lingkungan masyarakat setempat. Dakwah kultural juga bisa berarti kegiatan dakwah dengan memperhatikan potensi dan kecenderungan manusia sebagai makhluk budaya secara luas dalam rangka menghasilkan kultur baru yang bernuansa Islami atau kegiatan dakwah dengan memanfaatkan adat, tradisi, seni dan budaya lokal dalam proses menuju kehidupan Islami. ${ }^{7}$ Dakwah sesuai ragam

5 Awaludin Pimay, Paradigma Dakwah Humanis: Strategi dan Metode Dakwah Prof. KH. Saifudin Zuhri (Semarang: Rasail, 2005), 15.

6 Muhammad Sulthon, Desain Ilmu Dakwah (Yogyakarta: Pustaka Pelajar, 2003), 8.

7 Di Jawa dakwah kultural Islam lebih meniscayakan sebuah proses akulturasi dengan budaya lokal. Tanpa harus menanggalkan substansi ajaran keislaman, ekspresi lokalitasnya tetap dipertahankan. Lihat Zuhairi Misrawi, Hadratussyaikh Hasyim Asy'ari: Moderasi, Keumatan, dan Kebangsaan (Jakarta: PT. Kompas Media Nusantara, 2010), 131. 
kehidupan keagamaan sebagai proses sosial budaya itulah yang disebut dakwah kultural. Perubahan dari dakwah ini dilakukan secara bertahap, sesuai kondisi sosial-budaya masing-masing orang dan masyarakat. Hal ini didasari atas pandangan bahwa ke-kaffah-an Islamnya seseorang atau masyarakat itu mudah, menyenangkan, dan menggembirakan yang bisa dilakukan setiap orang selama masa hidupnya. Keberagaman sebagai proses sosial-budaya inilah, yang disebut sebagai Islam Kultural. ${ }^{8}$

Dakwah struktural adalah gerakan dakwah yang berada dalam kekuasaan. Aktivis dakwah struktural bergerak mendakwahkan ajaran Islam dengan memanfaatkan baik struktur sosial, politik, maupun ekonomi guna menjadikan Islam menjadi ideologi Negara sehingga nilai-nilai Islam mengejawantahkan dalam kehidupan berbangsa dan bernegara. Negara dipandang sebagai alat dakwah yang paling strategis. Dakwah stuktural memegang tesis bahwa dakwah yang sesungguhnya adalah ajaran Islam yang berusaha mewujudkan negara bangsa yang berdasar atas Islam, para pelaku politik menjunjung tinggi nilai-nilai keislaman dalam perilaku politik mereka, serta penegakan ajaran Islam menjadi tanggung jawab negara dan kekuasaan. Dalam perspektif dakwah struktural, negara adalah instrumen paling penting dalam kegiatan dakwah. ${ }^{9}$

Dengan demikian, juru dakwah yang berasal dari latar belakang kehidupan dan profesi yang berbeda sebenarnya tidak ada masalah asalkan memiliki kemampuan untuk menginterpretasikan ajaran Islam. Dakwah dapat berlangsung dalam kehidupan manusia, termasuk dalam arena politik kenegaraan. Secara umum dapat dikatakan bahwa politik dakwah tidak lain dari segala jenis kegiatan manusia yang berkaitan dengan masalah kekuasaan. Dalam pandangan Islam, politik hanyalah salah satu medium untuk mencapai tujuan dakwah. Bukan sebaliknya, dakwah justru dijadikan medium untuk mencapai tujuan politik. ${ }^{10}$ Sudah sering konsepsi dakwah dirumuskan, bahwa dakwah diselenggarakan

8 Abdul Munir Mulkhan, Kiai Ahmad Dahlan: Jejak Pembaruan Sosial dan Kemanusiaan: Kado Satu Abad Muhammadiyah (Jakarta: Kompas, 2010), 219.

${ }^{9}$ Sulthon, Desain Ilmu Dakwah, 26-28.

${ }^{10}$ Pimay, Paradigma Dakwah Humanis, 8-9. 
dan dilakukan untuk membantu $d a^{\prime} i$ memahami tujuan dan metode dakwah yang tepat. ${ }^{11}$ Jelas bahwa dakwah dapat membicarakan masalah metode dan teknik dakwah maka al-Qur'an dan Sunnah adalah sumber utama untuk pedoman. ${ }^{12}$

Sebagai lembaga dakwah yang mempunyai fungsi mengemban tugas agama dan risalah nubuwwah, pesantren hadir sebagai jawaban atas kebutuhan masyarakat terhadap lembaga keagamaan yang mengajarkan, mengembangkan, dan mengajarkan ilmu agama Islam. Dengan segala dinamikanya, pesantren dipandang sebagai lembaga pusat perubahanperubahan masyarakat yang melalui kegiatan dakwah Islam. ${ }^{13}$ Dalam kenyataan, hampir seluruh daerah atau pelosok di Indonesia terdapat ulama atau kiai yang dihasilkan dari pesantren. Mereka mempunyai peranan penting dalam membina masyarakat khususnya dalam pelaksanaan ajaran agama. Pesantren juga mengandung makna indigenous, artinya lembaga pendidikan asli Indonesia, ${ }^{14}$ yang apabila dipelajari lebih jauh di masa lampau ternyata pondok pesantren merupakan bentuk kebudayaan asli bangsa Indonesia. ${ }^{15}$

Pesantren setidaknya memiliki lima elemen dasar utama, yaitu 1) santri, yaitu orang-orang yang belajar mendalami ilmu-ilmu agama Islam di pesantren; 2) pondok sebagai tempat tinggal santri dan kelengkapan sarana prasarana pendukung proses belajar mengajar di pesantren; 3)

\footnotetext{
${ }^{11}$ Jalaludin Rahmat, et.al., Hegemoni Budaya (Yogyakarta: Yayasan Bentang Budaya, 1997), 49.

${ }^{12}$ Dzikron Abdullah, Metodologi Dakwah (Semarang: Fakultas Dakwah IAIN Walisongo Semarang, 1989), 23.

${ }^{13}$ Abdurrahman Mas'ud, et.al., Dinamika Pesantren dan Madrasah (Semarang: Fakultas Tarbiyah IAIN Walisongo Semarang dengan Pustaka Pelajar, 2002), 39.

${ }^{14}$ Nurcholis Madjid, Bilik-Bilik Pesantren: Sebuah Potret Perjalanan (Jakarta: Paramadina, 1997), 3.

${ }^{15}$ Pesantren disebut sebagai "Bapak" pendidikan Islam di Indonesia yang didirikan karena adanya tuntutan dan kebutuhan zaman dan apabila dilacak kembali sesungguhnya pesantren dilahirkan atas kesadaran adanya kewajiban dakwah Islamiah, sekaligus mencetak kader-kader ulama dan kiai. Lihat, Hasbullah, Dinamika Sistem Pendidikan Pesantren (Jakarta: PT Raja Grafindo Persada, 1999), 138.
} 
masjid, kedudukan masjid sebagai pusat pendidikan dalam tradisi pesantren merupakan manifestasi universal dari sistem pendidikan Islam; 4) sistem pembelajaran pondok pesantren, salah satu ciri utama pondok pesantren adalah pengajaran kitab-kitab kuning klasik; 5) kiai, merupakan elemen yang paling esensial dalam pesantren, bahkan seringkali ia merupakan pendiri pesantren itu, maka sudah sewajarnyalah pertumbuhan, maju atau mundurnya pesantren tergantung padanya. ${ }^{16}$

Kata "kiai" secara etimologis berasal dari bahasa Jawa kuno "kiyakiya", yang artinya orang yang dihormati. ${ }^{17}$ Sedangkan dalam pemakaianya dipergunakan untuk, pertama, benda atau hewan yang dikeramatkan, seperti kiai Plered (tombak), kiai Naga Wilaga (gamelan perayaan sekaten di Yogyakarta), kiai Rebo dan kiai Wage (gajah di kebun binatang Gembira Loka Yogyakarta); kedua, orang tua pada umumnya; ketiga, orang yang memiliki keahlian dalam agama Islam, yang mengajar santri di pondok pesantren. ${ }^{18}$ Sedangkan menurut Manfret Ziemek, pengertian kiai secara terminologis adalah pendiri dan pemimpin sebuah pesantren yang sebagai Muslim terpelajar telah membaktikan hidupnya demi Allah serta menyebarluaskan dan mendalami ajaran-ajaran dan pandangan Islam melalui kegiatan pendidikan Islam. ${ }^{19}$ Kekiaian dapat dibagi menjadi dua kategori dalam kaitannya dengan para pengikutnya. Kategori pertama adalah kiai yang mempunyai pengikut yang lebih banyak dan pengaruh yang lebih luas daripada kiai yang masuk kategori kedua. Pengaruh kiai yang masuk kategori pertama menyebar ke seluruh daerah. Kategori pertama ini terdiri dari kiai pesantren dan kiai tarekat. ${ }^{20}$ Kategori kedua terdiri dari kiai panggung dan kiai politik. Kiai panggung adalah para $d a^{\prime} i$. Mereka menyebarkan dan mengembangkan Islam

${ }^{16}$ Zamakhsari Dhofier, Tradisi Pesantren, Studi Tentang Pandangan Hidup Kyai (Jakarta: LP3ES, 1982), 44.

${ }^{17}$ M. Dawam Raharjo (ed.), Pesantren dan Pembaharuan (Jakarta: LP3ES, 1988), 12.

${ }^{18}$ Dhofier, Tradisi Pesantren, 55.

${ }^{19}$ Manfred Ziemek, Pesantren dalam Perubahan Sosial (Jakarta: P3M, 1986), 131.

${ }^{20}$ Endang Turmudi, Perselingkuhan Kiai dan Kekuasaan (Yogyakarta: PT. LKiS Pelangi Aksara, 2004), 32. 
melalui kegiatan dakwah. Sementara itu, kiai politik lebih merupakan kategori campuran. Mereka merujuk pada para kiai yang mempunyai perhatian untuk mengembangkan NU secara politis. Pengembangan NU dalam kurun waktu yang lama dikelola oleh kategori kiai ini yang tidak mempunyai pengikut seperti kiai lain. ${ }^{21}$

Dalam Islam, setiap Muslim memiliki kewajiban berdakwah karena pengertian subjek dakwah secara umum adalah setiap muslim atau muslimat yang mukallaf. Sementara secara khusus, mereka yang mengambil keahlian khusus (mutakhassis) dalam bidang agama Islam yang dikenal dengan ulama atau kiai. Maka, setiap Muslim mengemban tugas untuk menjadi teladan moral di tengah masyarakat. Dakwah akan efektif dan membuahkan hasil yang maksimal manakala juru dakwah konsisten antara kata dan tindakannya. Untuk itu, kata kunci dari keberhasilan dakwah adalah keteladanan. Hal ini menjadi menarik, ketika mengkaji keteladanan dakwah dalam konteks perilaku elit politik saat ini tampaknya menjadi suatu yang sangat relevan dakwah lewat politik dimunculkan. Dalam tulisan ini, penulis ingin mengkaji lebih dalam politik sebagai media dakwah. Penulis memulai dengan penjelasan mengenai dakwah dan dimensinya, kemudian dilanjutkan dengan paparan politik dan ruang lingkupnya, serta melalukan analisis politik dijadikan sebagai media dakwah.

\section{Konsep Dakwah}

Ditinjau dari segi etimologi da’i berasal berasal dari bahasa Arab, ${ }^{22}$ yaitu da'a, yad'u, da'watan. Jadi kata da'wah merupakan masdar dari kata da'a yang berarti ajakan, seruan, panggilan, undangan. Menurut para ulama Basrah, dasar pengambilan dakwah itu adalah masdar dari da'watan yang artinya penggilan. Sedangkan para Ulama Kufah berpendapat, perkataan dakwah itu diambil dari akar kata da’an, yang artinya

\footnotetext{
${ }^{21}$ Turmudi, Perselingkuhan Kiai dan Kekuasaan, 34.

${ }^{22}$ Mahmud Yunus, Kamus Arab Indonesia (Jakarta: Yayasan Penterjemah al-Qur'an, 2007), 27.
} 
telah memanggil. ${ }^{23}$ Dalam surat al-Baqarah ([2]: 186):

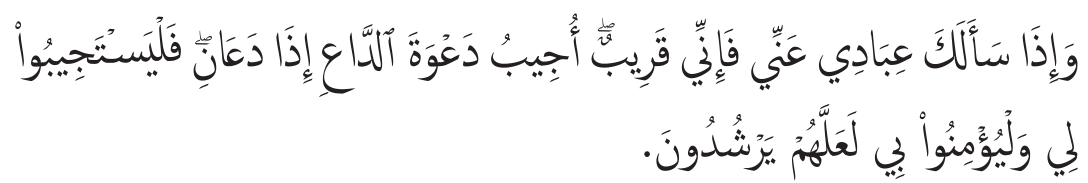

Dan apabila hamba-hamba-Ku bertanya kepadamu tentang aku, Maka (jawablah), bahwasanya Aku adalah dekat. Aku mengabulkan permohonan orang yang berdoa apabila ia memohon kepada-Ku, Maka hendaklah mereka itu memenuhi (segala perintah-Ku) dan hendaklah mereka beriman kepada-Ku, agar mereka selalu berada dalam kebenaran. ${ }^{24}$

Orang yang memanggil, mengajak atau menyeru melaksanakan dakwah dinamakan sebagai $d a^{\prime} i$. Jika yang menyeru atau $d a^{\prime} i$-nya terdiri dari beberapa orang (banyak) disebut, dengan du'ah. ${ }^{25}$ Ayat trsebut secara jelas menunjukkan bahwa kata dakwah memiliki dua pengertian yang berbeda. Pertama, dakwah sebagai seruan, ajakan, dan panggilan menuju surga, dan kedua, dakwah sebagai seruan, ajakan, dan panggilan menuju neraka. Karena itu, kata da'iyah atau $d a^{\prime} i$ (orang yang mengajak) juga mengandung dua pengertian: pertama, da'iyah atau da'i diartikan sebagai orang yang mengajak pada petunjuk. Kedua, da'iyah atau da'i diartikan sebagai orang yang mengajak pada kesesatan. Arti kata dakwah seperti yang terdapat dalam al-Qur'an Surat an-Nahl ([16]: 125) berikut:

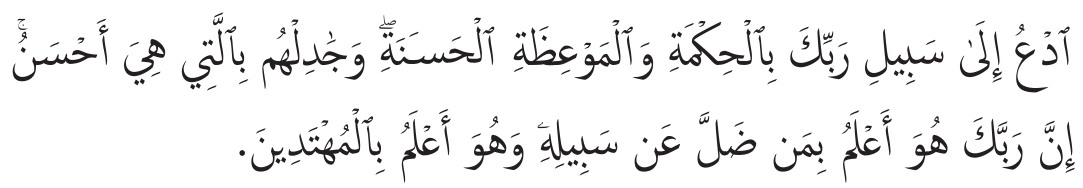

Serulah (manusia) kepada jalan Tuhan-mu dengan hikmah dan pelajaran yang yang baik dan bantahlah mereka dengan cara yang lebih baik. Sesungguhnya Tuhanmu Dialah yang lebih mengetahui

${ }^{23}$ Nazarudin, Publistik dan Dakwah (Jakarta: Erlangga, 1974), 87.

${ }^{24}$ Depag RI, Al-Qur'an dan Terjemahnya, 28.

${ }^{25}$ Asmuni Syukir, Dasar-dasar Strategi Dakwah Islam (Surabaya: Al-Ikhlas, 1983), 22; lihat juga Pimay, Paradigma Dakwah Humanis, 15. 
tentang siapa yang tersesat dari jalan-Nya dan Dia-lah yang lebih mengetahui orang-orang yang mendapat petunjuk. ${ }^{26}$

Jadi, dakwah menurut bahasa (etimologi) memiliki arti ajakan, seruan, panggilan, do'a kepada Allah SWT. Akan tetapi, kecenderungan banyak orang memakai kata dakwah untuk maksud ajakan, seruan, panggilan. Sedangkan arti dakwah menurut istilah (terminologi), juga terdapat banyak keanekaragaman. Para ahli ilmu mendefinisikan dakwah bermacam-macam pendapat, antara lain menurut Hamzah Ya'qub dalam bukunya Publistik Islam, bahwa dakwah Islam adalah mengajak umat manusia dengan hikmah kebijaksanaan untuk mengikuti petunjuk Allah dan Rasulullah. ${ }^{27}$ Dakwah, bagi Abu Bakar Zakaria, adalah bekerjanya para ulama dan orang-orang yang mempunyai pengetahuan dalam agama, mengajar orang banyak dari orang-orang umum, dan sesuatu yang membutuhkan mata mereka kepada urusan-urusan agama mereka menurut kemampuan. ${ }^{28}$ Arifin M. mendefinisikan dakwah sebagai suatu kegiatan ajakan baik dalam bentuk lisan, tulisan, tingkah laku dan sebagainya yang dilakukan secara sadar dan berencana dalam usaha mempengaruhi orang lain baik secara individu maupun secara kelompok agar timbul dalam dirinya suatu pengertian, kesadaran, sikap penghayatan serta pengamalan terhadap ajaran agama sebagai pesan yang disampaikan kepadanya dengan tanpa adanya unsur-unsur paksaan. ${ }^{29}$

Amrullah Achmad mengartikan dakwah Islam sebagai aktualisasi Imani, teologi yang dimanifestasi dalam suatu sistem kegiatan manusia beriman dalam bidang kemasyarakatan yang dilakukan secara teratur untuk mengetahui cara merasa, berpikir dan bertindak dalam rangka mengusahakan terwujudnya ajaran Islam dalam semua segi kehidupan

\footnotetext{
${ }^{26}$ Depag RI, Al-Quran dan Terjemahnya, 224.

${ }^{27}$ Hamzah Ja'qub, Publistik Islam dan Dakwah (Bandung: CV. Diponegoro, 1973), 27.

${ }^{28}$ A. Hasjmy, et.al., Pengantar Ilmu Dakwah (Proyek Pembinaan Perguruan Tinggi Agama IAIN Jami'ah ar-Raniry Darussalam, 1984/1985), 2.

${ }^{29}$ M. Arifin, Psikologi Da'wah: Suatu Pengantar Studi (Jakarta: Bulan Bintang, 1977), 17.
} 
dengan menggunakan cara tertentu. ${ }^{30}$ A. Hasjmy dalam Dustur Da'wah Menurut al-Qur'an mengatakan, dakwah adalah mengajak orang lain untuk meyakini dan mengamalkan aqidah dan syariat Islam yang lebih dulu telah diyakini dan diamalkan oleh pendakwah sendiri. ${ }^{31}$

Menurut Dzikron Abdullah, dakwah adalah semua usaha untuk menyebarluaskan Islam dan merealisasikan ajarannya dalam kehidupan masyarakat agar memeluk Islam dan mengamalkannya. ${ }^{32}$ Sementara Ahmad Syafi'i Ma'arif mengartikan dakwah Islam merupakan suatu usaha atau kerja bagaimana berdakwah itu dapat menggarami kehidupan umat manusia dengan nilai-nilai Iman, Islam dan takwa demi kebahagiaan kita di masa kini dan masa nanti. ${ }^{33}$

Dari beberapa definisi di atas berbeda redaksinya, tetapi setiap redaksinya memiliki tiga unsur pengertian dasar (pokok) adalah:

a. Dakwah adalah proses penyampaian agama Islam oleh seseorang kepada orang lain.

b. Dakwah adalah proses penyampaian ajaran Islam, yang berupa amar ma'ruf nahi munkar (ajaran lepada kebaikan dan mencegah kemungkaran).

c. Usaha tersebut dilakukan secara sadar dengan tujuan terbentuknya statu individu atau masyarakat yang taat dan mengamalkan sepenuhnya ajaran Islam. ${ }^{34}$

Dari beberapa definisi, penulis menyimpulkan bahwa dakwah adalah segala sesuatu yang dilakukan dengan wujud sikap, ucapan, dan perbuatan yang mengandung ajakan atau seruan baik langsung atau tak

\footnotetext{
${ }^{30}$ Amrullah Achmad (ed.), Dakwah Islam dan Perubahan Sosial (Yogyakarta: PLP2M, 1985), 2.

${ }^{31}$ A. Hasjmy, Dustur Da'wah Menurut al-Qur'an (Jakarta: Bulan Bintang, 1974), 28.

${ }^{32}$ Dzikron Abdullah, Metode Da'wah (Semarang: Fakultas Dakwah IAIN Walisongo, 1982), 7.

${ }^{33}$ Ahmad Syafi'i Ma’arif, Membumikan al-Qur'an (Yogyakarta: Pustaka Pelajar, 1995), 101.

${ }^{34}$ Moh. Ali Aziz, Ilmu Dakwah (Jakarta: Kencana, 2004), 10.
} 
langsung ditujukan pada perorangan atau masyarakat agar mengetahui, mengimani, dan mengamalkan ajaran Islam dalam segala segi kehidupan, dilakukan oleh orang Islam baik individual atau jama'ah secara bijaksana. Dapat ditegaskan, dengan merujuk pada tiga unsur di atas dakwah adalah segala bentuk aktivitas penyampaian ajaran Islam kepada orang lain dengan berbagai cara dan sarana yang bijaksana untuk terciptanya individu dan masyarakat yang menghayati dan mengamalkan ajaran Islam dalam semua segi kehidupan.

\section{Dasar Hukum Dakwah}

Berdakwah dengan segala bentuknya adalah wajib hukumnya bagi setiap manusia. Dakwah antara lain berupa amar ma'ruf, nahi munkar, berjihad memberi nasihat dan sebagainya. Kurang tepat apabila ada asumsi bahwa dakwah seolah-olah menjadi kewajiban para ulama, kiai, mubalig, ustaz saja. Sedangkan selain mereka tidak ada kewajiban untuk melaksanakan tugas berdakwah Islamiah. Dakwah sebagai kewajiban setiap Muslim yang telah banyak dijelaskan dalam al-Qur'an dan diperjelas di dalam Hadis. Dalam al-Qur'an di antaranya terdapat pada Surat Ali Imran ([3]: 104) sebagai berikut.

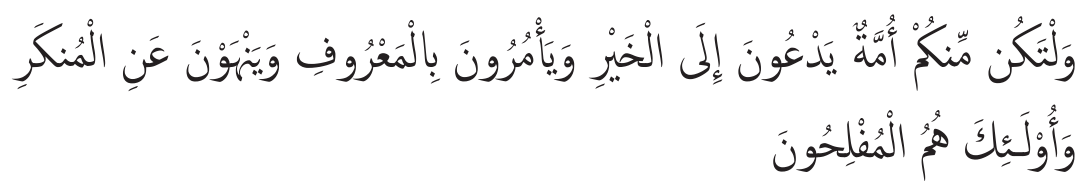

Dan hendaklah di antara kamu ada segolongan orang yang menyeru kepada kebajikan, menyeru (berbuat) yang ma'ruf, dan mencegah dari mungkar. Dan mereka itulah orang-orang yang mendapat azab yang berat.

Dalam al-Qur'an Surat an-Nahl ([16]: 125), Allah juga memerintahkan manusia untuk melakukan dakwah, yaitu dengan mengajak umat ke jalan Allah dengan cara yang bijaksana, nasihat yang baik serta berdebat dengan cara yang baik pula. ${ }^{35}$ Perintah untuk amar ma'ruf nahi munkar,

\footnotetext{
${ }^{35}$ Syukir, Dasar-Dasar Strategi Dakwah, 19.
} 
juga terdapat dalam Hadis Nabi Muhammad Saw. sebagai berikut:

$$
\text { بَلغُوْا عَنى وَلوْ ايَة (رواه البخارى) }
$$

Sampaikanlah dariku walau satu ayat. (H.R. Bukhori) ${ }^{36}$

Dalam Hadis yang lain juga dijelaskan, yang artinya "Dari Abu Hurairoh R.A. berkata: Rasulullah bersabda: Barang siapa di antara kamu melihat kemungkaran maka hendaklah dia mengubah dengan tangannya, apabila tidak kuasa maka dengan lidahnya, apabila tidak kuasa maka dengan menggunakan hatinya, yang demikian itu selemahlemahnya iman (H.R. Muslim)." ${ }^{37}$ Selemah-lemahnya keadaan seseorang, setidaknya ia masih memiliki kewajiban menolak kemungkaran dengan hatinya, jika ia masih ingin dianggap Allah Swt. sebagai orang yang masih memiliki iman, maka penolakan kemungkaran dengan hati merupakan benteng penghabisan tempat berdiri. Berdasarkan Hadts di atas mengisyaratkan bahwa berdakwah melalui profesi yang dimiliki seorang Muslim atau $d a^{’} i$ juga cara terbaik dalam mencapai tujuan dakwah.

\section{Fungsi dan Tujaun Dakwah}

Nabi Muhammad SAW diutus untuk menyempurnakan kehidupan manusia, agama Islam memiliki ide dan missi untuk kesejahteraan ummat manusia di dunia dan akhirat. Oleh sebab itu, dakwah merupakan aktivitas yang memiliki peran strategis. Ajaran Islam dapat dipelajari, dihayati, dan diamalkan oleh manusia; sebaliknya tanpa adanya aktivitas dakwah terputuslah siklus penyebaran nilai-nilai ajaran Islam agar individu mantap baik dalam akidah, ibadah maupun akhlaknya sehingga diharapkan lahir masyarakat yang ideal berada di bawah naungan Allah Swt. Di sinilah dakwah diperlukan untuk membina mental dan spiritual manusia agar sesuai dengan ajaran Allah Swt. seperti yang disampaikan oleh Rasulullah Saw. Dari uraian di atas, dapat disebutkan fungsi dakwah adalah:

\footnotetext{
${ }^{36}$ Imam Bukhari, Shahih Bukhari (Istambul: Darul Fikr, ND).

${ }^{37}$ Imam Muslim, Shahih Muslim (Qahira: Maktabah Masyhad al-Husainy, 2000), 88.
} 
1. Dakwah berfungsi untuk menyebarkan Islam kepada manusia sebagaimana individu dan masyarakat sehingga mereka merasakan.

2. Islam benar-benar sebagai rahmatan lil 'alamin bagi seluruh makhluk. Allah berfirman dalam Q.S. al-Anbiya ([21]: 108), yang artinya, "Katakanlah: "Sesungguhnya yang diwahyukan kepadaku adalah: bahwa Tuhanmu adalah Tuhan yang Esa. Maka hendaklah kamu berserah diri (kepada-Nya)."

3. Dakwah berfungsi untuk melestarikan nilai-nilai Islam dari generasi ke generasi kaum Muslimin berikutnya sehingga kelangsungan ajaran Islam beserta pemeluknya dari generasi ke generasi tidak terputus.

4. Dakwah berfungsi korektif, artinya meluruskan akhlak yang bengkok, mencegah kemungkaran, dan mengeluarkan manusia dari kegelapan rohani. ${ }^{38}$

Dakwah merupakan suatu rangkaian kegiatan atau proses, dalam rangka mencapai tujuan tertentu. Tujuan ini dimaksud untuk memberi arah atau pedoman bagi gerak langkah kegiatan dakwah. Sebab tanpa tujuan yang jelas, seluruh aktivitas akan sia-sia atau tidak ada artinya. Dengan demikian, tujuan dakwah sebagai bagian seluruh aktivitas dakwah. Bahkan lebih dari itu tujuan dakwah sangat menentukan dan berpengaruh terhadap penggunaan metode dan media dakwah, sasaran dakwah sekaligus strategi dakwah. ${ }^{39}$ Dalam sebuah Hadis disebutkan: ${ }^{40}$

Sesungguhnya segala pekerjaan dengan niat, dan bahwasanya bagi setiap urusan (perkara) tergantung dengan apa yang diniatinya. Maka barang siapa yang berhijrah menuju keridhaan Allah dan RasulNya, maka hijrahnya karena Allah dan RasulNya, dan barang siapa yang berhijrah karena dunia (harta atau kemenangan

${ }^{38}$ Aziz, Ilmu Dakwah, 60.

${ }^{39}$ Syukir, Dasar-dasar Strategi Dakwah, 40.

${ }^{40}$ Imam Nawawi al-Bantani, Hadits Arbain an-Nawawiyah (terjemahan). Cet. IV (Surabaya: Media Insani Press, 2003), 10. 
dunia) atau karena wanita yang dikawininya, maka hijrahnya itu ke arah tujuan.

Setiap kegiatan yang dilakukan pasti memiliki tujuan yang hendak dicapai. Secara umum dan secara khusus tujuan dakwah dapat dirumuskan dalam tiga bentuk, yakni sebagai berikut:

a. Membangun masyarakat Islam, sebagimana para rasul yang memulai dakwahnya di kalangan masyarakat jahiliyah, para rasul mengajak manusia memeluk agama Allah, menyampaikan wahyu kepada kaumnya, dan memperingatkan mereka dari syirik kepada Allah Swt.

b. Dakwah dengan melakukan perbaikan pada masyarakat Islam yang terkena "musibah" berupa penyimpangan dan nampak di dalamnya kemungkaran-kemungkaran, serta diabaikannya kewajiban-kewajiban oleh masyarakat.

c. Memelihara keberlangsungan dakwah di kalangan masyarakat yang telah berpegang pada kebenaran, yaitu dengan pengajaran secara terus-menerus, tadziri (pengingatan), tazkiyah (penyucian jiwa), dan ta'lim (pendidikan). ${ }^{41}$

Sedangkan secara khusus tujuan dakwah adalah sebagai berikut:

a. Menganjurkan dan menunjukkan perintah-perintah Allah. Perintah Allah secara garis besar dapatlah dibilang ada dua yakni Islam dan Iman.

b. Menunjukkan larangan-larangan Allah. Larangan ini meliputi larangan-larangan yang bersifat perbuatan (amaliah), perkataan (qauliah).

c. Menunjukkan keuntungan-keuntungan bagi kaum yang mau bertakwa kepada Allah.

d. Menunjukkan ancaman yang ingkar kepadanya. ${ }^{42}$

\footnotetext{
${ }^{41}$ Aziz, Ilmu Dakwah, 62.

${ }^{42}$ Syukir, Dasar-dasar Strategi Dakwah, 55-56.
} 


\section{Unsur-Insur Dakwah}

Yang dimaksud dengan unsur-unsur dakwah adalah komponenkomponen yang selalu ada dalam setiap kegiatan dakwah. Unsur-unsur tersebut adalah da'i (pelaku dakwah), mad'u (mitra dakwah), maddah dakwah (materi dakwah), wasilah dakwah (media dakwah), thariqoh dakwah (metode dakwah), dan atsar (efek dakwah).

Pertama, da’i (pelaku dakwah), yaitu orang yang melakukan dakwah baik dengan lisan, tulisan, ataupun perbuatan, baik secara individu, kelompok atau berbentuk lembaga (organisasi). Kewajiban dakwah (amar ma'ruf nahi munkar) berlaku atas setiap Muslim yang mukallaf (yang telah berlaku hukum-hukum agama atas dirinya) dan memiliki kemampuan. ${ }^{43}$ Kata da'i ini secara umum sering disebut dengan sebutan mubaligh (orang yang menyempurnakan ajaran Islam), tapi sebenarnya sebutan ini berkonotasi sangat sempit karena masyarakat umum cenderung mengartikan sebagai orang yang menyampaikan ajaran Islam melalui lisan seperti penceramah agama, khatib (orang yang berkhutbah), dan sebagainya.

Kedua, mad'u (mitra dakwah), yaitu pihak yang menjadi sasaran dakwah atau penerima pesan dakwah, baik individu maupun kelompok, baik manusia yang beragama Islam maupun tidak; atau dengan kata lain manusia secara keseluruhan. Sesuai dengan firman Allah Surat Saba' ([34]: 28) berikut:

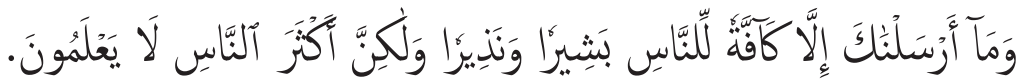

Dan kami tidak mengutus kamu, melainkan kepada umat manusia seluruhnya sebagai pembawa berita gembira dan sebagai pemberi peringatan, tetapi kebanyakan manusia tiada mengetahui.

Kepada manusia yang belum beragama Islam, dakwah bertujuan untuk mengajak mereka mengikuti agama Islam; sedangkan kepada

\footnotetext{
${ }^{43}$ Abu Hamid al-Ghazali, Amar Ma'ruf Nahi Munkar, terj. Muhammad Bagir (Bandung: Penerbit Karisma, 2003), 35.
} 
orang-orang yang telah beragama Islam dakwah bertujuan meningkatkan kualitas iman, Islam, dan ihsan. Mereka yang menerima dakwah ini lebih tepat disebut mitra dakwah daripada sebutan obyek dakwah sebab sebutan yang kedua lebih mencerminkan kepasifan penerima dakwah, padahal sebenarnya dakwah merupakan tindakan yang menjadikan orang lain sebagai kawan berpikir tentang keimanan, syariah, dan akhlak kemudian untuk diupayakan dihayati, dan diamalkan bersama-sama. ${ }^{44}$

Ketiga, maddah da'wah (materi dakwah), yaitu masalah isi pesan atau materi yang disampaikan $d a^{\prime} i$ kepada mad'u dalam hal ini sudah jelas. Maddah dakwah adalah ajaran Islam yang secara umum meliputi akidah, akhlak, dan syariah. Secara garis besar dapat dikelompokkan sebagai berikut:

1. Akidah, yang meliputi enam rukun iman (iman kepada Allah, malaikat, kitab-kitab Allah, rasul-rasul, kiamat, qadha dan qadhar).

2. Syariah, meliputi ibadah (dalam arti khusus) seperti sholat, zakat, puasa (shaum), haji, thaharah, dan sebagainya;

3. Muamalah (dalam arti yang luas) meliputi al-qununul khas (hukum perdata), hukum niaga, hukum nikah, dan hukum waris; dan al-qununul 'am (hukum publik) yang terdiri dari jinayah (hukum pidana), khilafah (hukum negara), dan jihad (hukum perang dan damai).

4. Akhlak, meliputi akhlak terhadap Khaliq, akhlak terhadap makhluk, yang meliputi; Akhlak terhadap manusia: 1) diri sendiri, 2) tetangga, 3) masyarakat lainya. Akhlak terhadap selain manusia: 1) flora, 2) fauna, dan lain sebagainya. ${ }^{45}$

Keempat, wasilah da'wah, yaitu alat yang digunakan untuk menyampaikan materi dakwah, yang dapat berupa lisan, tulisan, lukisan audiovisual ataupun akhlak. Untuk menyampaikan ajaran Islam kepada umat,

\footnotetext{
${ }^{44}$ Aziz, Ilmu Dakwah, 90.

${ }^{45}$ Ibid., 94-95.
} 
dakwah dapat menggunakan berbagai wasilah. Hamzah Ya’qub membagi wasilah dakwah menjadi lima macam, yaitu lisan, tulisan, lukisan, audiovisual, dan akhlak.

a. Lisan, yaitu wasilah dakwah yang paling sederhana yang menggunakan lidah dan suara, dakwah dengan wasilah ini dapat berbentuk pidato, ceramah, kuliah, penyuluhan, dan sebagainya.

b. Tulisan, buku majalah, surat kabar, surat menyurat (korespondensi) spanduk, dan sebagainya.

c. Lukisan, gambar, karikatur, dan sebagainya.

d. Audio-visual, yaitu alat dakwah yang merangsang indra pendengaran atau penglihatan dan kedua-duanya, televisi, film, internet, dan sebagainya.

e. Akhlak, yaitu perbuatan-perbuatan nyata yang mencerminkan ajaran Islam dapat dinikmati, serta didengarkan oleh mad'u.

Dari segi media penyampaian pesan, media dakwah dibagi menjadi tiga golongan.

a. The spoken words, yaitu media dakwah yang berbentuk ucapan atau alat yang dapat ditangkap dengan indra telinga.

b. The printed words, yaitu media dakwah yang berupa tulisan, gambar, lukisan dan media lain yang dapat diterima dengan indra penglihatan.

c. Audio visual, yaitu media dakwah yang berbentuk gambar hidup yang dapat didengar sekaligus dapat dilihat seperti televisi, film, video, dan sebagainya. ${ }^{46}$

Kelima, thariqah da'wah (metode dakwah), yakni metode yang digunakan dalam berdakwah, yaitu dengan jalan atau cara dipakai $d a^{\prime} i$ untuk menyampaikan ajaran Islam (materi dakwah) ${ }^{47}$ Setiap unsur dakwah antara yang satu dengan yang lain selalu memiliki kaitan yang

\footnotetext{
${ }^{46}$ Ibid., 121.

${ }^{47}$ Ibid., 122.
} 
erat, sehingga metode dakwah merupakan lanjutan dari media dakwah. Secara garis besar dalam AlQur'an Surat an-Nahl ([16]: 125) telah dijelaskan metode dakwah adalah hikmah, mauidhotil hazaña, mujadalah. ${ }^{48}$ Menurut Sayyid Qutub, hikmah adalah meliat situasi dan kondisi obyek dakwah, serta tingkat kecerdasan penerima dakwah. Memperhatikan kadar materi dakwah yang disampaikan kepada mereka sehingga mereka tidak merasa terbebani terhadap perintah agama (materi dakwah) tersebut, karena belum siap mental untuk menerimanya. Memperhatikan metode penyampaian dakwah dengan bermacam-macam metode yang mengunggah perasaan, tidak memancing kemarahan, penolakan, kecemburuan, dan terkesan berlebih-lebihan sehingga tidak mengandung hikmah di dalamnya. Sedangkan mau'izhah al-hasanah (dengan pelajaran yang baik) dipahami oleh banyak pakar ilmu dakwah dari sudut pemahaman, yaitu kemampuan juru dakwah dalam memilih materi dakwah itu sendiri. Al-Baidlawy mengatakan bahwa mau'izhah alhasanah adalah perkataan yang menyejukkan dan perumpamaan. Salah satu perwujudan dari dakwah al-hikmah dan diterapkan mau'izhah alhasanah itu memiliki hubungan yang sangat erat. Juru dakwah yang berperilaku baik akan selalu diamati, dihormati, dan disegani serta dijadikan comtoh yang terpuji bagi masyarakat. Menurut Sayyid Quthub, dakwah bi al-mujadalah bi al-laty hiya ahsan adalah dakwah yang tidak mengandung unsur pertikaian, kelicikan, dan kejelekan sehingga mendatangkan ketenangan dan kelegaan bagi juru dakwah. Dengan demikian, mujadalah tidak dilakukan oleh orang-orang yang berada dari golongan awam atau orang-orang yang berada di antara golongan cerdik, pandai, terpelajar, dan memiliki wawasan yang luas, karena dalam kehidupan seharí-harinya mereka telah terbiasa berpikir kritis dan rasional. ${ }^{49}$

Keenam, atsar (efek dakwah). Setiap aksi dakwah pasti akan menimbulkan reaksi. Demikian jika dakwah telah dilakukan oleh seorang da'i dengan materi dakwah, wasilah, thariqah tertentu maka akan timbal respons dan efek (atsar) pada mad'u. Atsar itu sendiri sebenarnya berasal

\footnotetext{
${ }^{48}$ Pimay, Paradigma Dakwah Humanis, 56.

${ }^{49}$ Ibid., 69.
} 
dari bahasa Arab yang berarti bekasan, sisa, atau tanda. Istilah ini kemudian digunakan untuk menunjukkan statu ucapan atau perbuatan yang berasal dari sahabat atau tabi'in yang pada perkembangan selanjutnya dianggap sebagai Hadis, karena memiliki ciri-ciri sebagai Hadis. ${ }^{50}$ Atsar yang sering disebut dengan feedback (umpan balik) dari proses dakwah ini seringkali dilupakan atau tidak banyak menjadi perhatian para $d a^{\prime} i$ kebanyakan mereka menganggap bahwa setelah dakwah disampaikan maka selesailah dakwah. Padahal, atsar sangat besar artinya dalam penentuan langkah-langkah dakwah berikutnya. Tanpa menganalisis atsar dakwah, maka kemungkinan kesalahan strategi yang sangat merugikan pencapaian tujuan dakwah akan terulang kembali. Sebaliknya, dengan menganalisis atsar dakwah secara cermat dan tepat maka kesalahan strategis dakwah akan segera diketahui untuk diadakan penyempurnaan pada langkah-langkah berikutnya, demikian juga strategi dakwah termasuk di dalam penentuan unsur-unsur dakwah yang dianggap baik dapat ditingkatkan. ${ }^{51}$

\section{Politik dan Ruang Lingkupnya}

Kata politik berasal dari polis yang berarti negara kota (Yunani). Secara etimologi atau secara harfiah berbicara tentang politik adalah berbicara tentang negara. Ada beberapa unsur-unsur politik pada suatu wilayah tertentu mempunyai batas-batas tertentu yang telah diterapkan dan disepakati oleh pihak-pihak yang berkepentingan.

a. Adanya penduduk atau rakyat yang mendiami wilayah tertentu itu secara konstan dan bertambah dengan pengertian tidak berpindah meninggalkan wilayah yang lain.

b. Adanya suatu pemerintahan yang mengatur rakyat dan wilayahnya, serta mampu mempertahankan rakyat dan wilayahnya itu.

c. Adanya kekuasaan di dalam negara itu mampu mengatur hubungan ke dalam dan ke luar.

\footnotetext{
${ }^{50}$ Abuddin Nata, Metodologi Studi Islam (Jakarta: Raja Grafindo Persada, 1998), 363.

${ }^{51}$ Aziz, Ilmu Dakwah, 138.
} 
d. Adanya pengakuan dari dunia internasional bahwa negara itu telah mampu mengatur hubungan dengan negara-negara lain serta mampu mengurus negaranya sendiri. ${ }^{52}$

Secara garis besar, politik adalah berkenaan dengan kekuasaan pengaruh, kewenangan pengaturan, dan ketaatan atau ketertiban. ${ }^{53}$ Menurut Roger F. Soltau, ilmu politik adalah mempelajari negara, tujuan-tujuan negara, dan lembaga-lembaga yang akan melaksanakan tujuan-tujuan itu, hubungan antarnegara dengan warga negaranya, serta dengan negara-negara dalam melakukan tugas-tugasnya. ${ }^{54}$

Politik seperti yang dikemukakan oleh Thompson berada pada dunia kekuasaan. Politik sebagai alat untuk mengejar kekuasaan sering perlu mengunakan komunikasi yang 'keras' untuk mempengaruhi opini atau sikap masyarakat. ${ }^{55}$ Proses komunikasi politik memang tak jarang memakai jarum suntik (hypodermic leedle model) oleh para elit politik kepada masyarakat "awam" agar opini publik cepat berubah sesuai dengan para elit politik. ${ }^{56}$

Jika ditinjau dari segi kenyataan dan dibandingkan dengan ukuranukuran politik masa modern dapat kita katakan bahwa tata aturan itu merupakan tata aturan politik sebab hakikat Islam mencakup segi-segi kebendaan (maddiyah), kejiwaan (ruhiah), dan segala amal insani dalam kehidupan duniawiah dan ukhrawiah. ${ }^{57}$ Agama ialah suatu sistem tata keyakinan (kredo) dan peribadatan (ritual) manusia kepada Yang Maha Mutlak, serta suatu sistem tata kaidah (norma-etika) yang mengatur hubungan manusia dengan sesama manusia dan dengan alam lainnya

\footnotetext{
${ }^{52}$ Winardi, Pengantar Ilmu Politik (Jakarta: Mandar Maju, 1994), 4.

${ }^{53}$ Teuku May Rudy, Pengantar Ilmu Politik, Wawasan Pemikiran dan Kegunaanya (Bandung: PT. Eresco, 1993), 7.

${ }^{54}$ Cheppy Hari Cahyono, Ilmu Politik dan Perspektifnya (Yogyakarta: Tiara Wacana, 1991), 8 .

${ }^{55}$ A. Muis, Komunikasi Islam (Bandung: PT. Remaja Rosdakarya, 2001), 117.

${ }^{56}$ Ibid., 119.

${ }^{57}$ Tengku Muhammad Hasbi ash-Shiddiqi, Islam dan Politik Bernegara (Semarang: PT. Pustaka Rizki Putra, 2002), 5.
} 
sesuai dngan tata keimanan dan tata peribadatan..$^{58}$

Dilihat dari pentingnya agama bagi manusia, Surbakti menyatakan bahwa ada dua konsep mendasar agama bagi kehidupan manusia, yaitu agama dalam arti what religion does dan what is religion. Pengertian pertama mengacu pada apa fungsi agama bagi kehidupan manusia, sementara pengertian yang kedua mengacu pada apa makna agama bagi manusia. ${ }^{59}$ Perbincangan seputar hubungan agama dengan negara adalah sebuah wacana klasik. Akan tetapi, meski telah menjadi subjek diskusi selama berabad-abad sebab persoalan tersebut tidak terjawab secara tuntas. Dan di era yang semakin kompleks saat ini, diskusi tentang hubungan antara keduanya semakin hangat dan marak diperbincangkan bersamaan dengan isu terorisme yang dihubungkan dengan agama tertentu sebab pada dasarnya agama sebagai sistem kepercayaan memang memiliki hubungan dengan aspek politik. Dalam realitasnya, semua pemeluk agama meyakini bahwa agama memberikan kerangka makna dan cara pandang bagi individu ataupun masyarakat, termasuk di dalamnya aspek politik.

Berkaitan dengan keberadaan dua institusi tersebut, Kuntowijoyo menyatakan bahwa agama dan negara adalah dua satuan sejarah yang berbeda hakikatnya. Agama adalah kabar gembira dan peringatan (basira wa nadzira), sedangkan negara adalah kekuatan pemaksa (coercion). Agama mempunyai khatib, juru dakwah, dan ulama, sedangkan negara mempunyai birokrasi pengadilan dan tentara. Agama dapat memengaruhi jalannya sejarah melalui kesadaran bersama, sementara negara mempunyai pengaruh sejarah dengan keputusan, kekuasaan, dan perang. Agama adalah kekuatan dari dalam, sementara negara adalah kekuatan dari luar. ${ }^{60}$

Mengenai hubungan antara agama dan negara dalam konteks religio-politik, Smith mengajukan dua model system, yaitu model organik

\footnotetext{
${ }^{58}$ Endang Saifudin Anshari, Kuliah al-Islam (Jakarta: Rajawali, 1992), 33.

${ }^{59}$ Donald Eugene Smith, Agama dan Modernisasi Politik: Suatu Kajian Analitis (Jakarta: Rajawali Press, 1985), 187-188.

${ }^{60}$ Kuntowijoyo, Identitas Politik Umat Islam (Bandung: Mizan, 1997), 191-192.
} 
dan model gereja. Model organik adalah konsep tentang penggabungan fungsi-fungsi keagamaan dan politik yang dilakukan oleh struktur yang tunggal. Penguasa menjalankan kekuasaan duniawi dan spiritual keagamaan sekaligus, dan fungsi utamanya adalah menegakkan tatasosial yang bersifat keutuhan sesuai dengan hukum dan tradisi agama yang sakral. Adapun yang termasuk dalam model ini adalah agama Islam dan Hindu. Sedangkan model gereja di tandai dengan ikatan yang erat antara dua lembaga yang berbeda satu sama lain yaitu pemerintah dan institusi keagamaan. Akan tetapi, yang satu dengan yang lain dapat saling bertukar fungsi secara ekstensif di bidang politik dan keagamaan. Secara empirik, kedua lembaga tersebut terpisah sehingga hubungan keduanya dapat menggunakan tiga bentuk, yaitu gereja di atas pemerintah, pemerintah di atas gereja, dan dengan keseimbangan kekuasaan antara keduanya. Yang termasuk dalam model ini adalah agama Katolik dan agama Budha.

Selanjutnya, perlu dikemukakan di sini bahwa politik adalah bermacam-macam aktivitas dalam suatu sistem negara yang berkaitan dengan proses menentukan dan melaksanakan tujuan-tujuan dari sistem tersebut. Secara lebih rinci, Surbakti menjelaskan bahwa politik adalah interaksi antara pemerintah dan masyarakat dalam rangka proses pembuatan dan pelaksanaan keputusan yang mengikat tentang kebaikan bersama masyarakat yang tinggal dalam suatu wilayah tertentu. Berdasarkan definisi ini, ia menyimpulkan bahwa terdapat empat aspek dalam politik, yaitu perilaku politik, pemerintah dan masyarakat, keputusan untuk kebaikan bersama (public good), dan konflik, konsensus, dan perubahan. ${ }^{61}$

Dalam konteks keindonesiaan, menurut Adnan, hubungan agama dan negara dapat dibagi menjadi tiga kategori. Pertama, kelompok akomodatif. Kelompok ini dipelopori oleh Nurcholis Madjid yang berpandangan bahwa kehidupan spiritual diatur oleh agama dan kehidupan duniawi diatur oleh logika duniawi. Pemikiran ini seolah mengandung elemen sekularistik, yaitu adanya upaya memisahkan antara agama dengan dunia, meskipun yang sebenarnya hanyalah pembedaan wilayah:

\footnotetext{
${ }^{61}$ Ramlan Surbakti, Memahami Ilmu Politik (Jakarta: Gramedia, 1992), 11.
} 
ada wilayah yang semata-mata duniawi. ${ }^{62}$ Pemikiran seperti ini dapat mengalihkan perhatian masyarakat dari "Islam politik" ke "Islam kultural". Akibatnya, Islam lebih berwatak liberalis dan humanis yang menawarkan kebebasan dan kemanusiaan bagi penganutnya, daripada watak politis yang menakutkan, utamanya bagi penyelenggara negara. ${ }^{63}$ Di kalangan Nahdhatul Ulama (NU), pemikiran akomodatif dapat dilihat pada diri Abdurrahman Wahid (Gus Dur) yang sukses menarik gerbong UN ke Khittah 1926 dan berhasil memisahkan NU dari politik praktis. Dengan demikian, tidak ada lagi politik Islam dan juga tidak ada lembaga politik Islam, atau dengan kata lain, ia menegaskan pentingnya eksistensi lembaga politik Islam. ${ }^{64}$

Kedua, kelompok moderat, dengan tokohnya Amien Rais, Jalaluddin Ramat, dan Imaduddin Abdurrahim. Kelompok ini berpendirian bahwa Islam tidak hanya dipahami sebagai agama, tetapi juga sebagai ideologi. Islam adalah agama totalistik ( $k a f f a h)$ yang mengatur segala aspek kehidupan masyarakat, termasuk di dalamnya kehidupan sosial-politik.

Ketiga, kelompok idealis-radikal. Kelompok ini beranggapan bahwa Islam berada di atas semua ideologi sehingga untuk memperjuangkannya diperlukan cara-cara kekerasan dan sekaligus menolak ideologi Pancasila sebagai satu-satunya asas bagi kehidupan organisasi sosial kemasyarakatan dan bahwa agama harus menjadi ideologi menggantikan Pancasila. Pandangan ini dapat dilihat pada visi dan aksi Abdul Qadir Jaelani. ${ }^{65}$

${ }^{62}$ Nurcholis Madjid, Islam Keindonesiaan dan Kemoderan (Jakarta: Paramadina, 1993), 92.

${ }^{63}$ Muhammad Kamal Hasan, Modernisasi Indonesia: Respons Cendekiawan Muslim (Surabaya: Bina Ilmu, 1987), 231-240.

${ }^{64}$ Abdurrahman Wahid, "Politik Sebagai Moral, Bukan Institusi," Majalah Prisma, No. 5 (1995).

${ }^{65}$ Hasan, Modernisasi Indonesia, 244-246. 


\section{Politik Sebagai Media Dakwah}

Kata media secara etimologis berasal dari bahasa Latin, median, yang berarti alat perantara. Dengan demikian, media dakwah ialah segala sesuatu yang dapat dijadikan sebagai alat (perantara) untuk mencapai tujuan tertentu. ${ }^{66}$ Maka dalam hal ini, media dakwah mempunyai peranan atau kedudukan yang sama dibandingkan dengan komponen yang lain, seperti metode dakwah, obyek dakwah, dan sebagainya.

Politik cenderung berpecah dan memecah, dakwah merangkul dan mempersatukan. Dalam perspektif al-Qur'an, politik seharusnya menjadi filosofi dakwah sebagai acuan, tetapi alangkah sulitnya, termasuk realitas yang sering kita tonton dalam kelakuan partai-partai yang mengaku berdasarkan Islam. Mereka sikut-menyikut, perang ayat, masing-masing ingin 'memaksa' Tuhan untuk berpihak kepada kepentingan jangka pendeknya, berupa posisi politik dan ekonomi. Perbedaan fundamental antara kelakuan politik mereka rajin ke masjid dan sebagainya, kalau jubah dakwah ingin mengubah.

Menurut Saifudin Zuhri, politik sebenarnya memiliki tujuan yang positif, antara lain, pertama, menata masyarakat dengan landasan akhaq al-karimah. Kedua, menggugah mereka dengan hikmah yang mulia. Ketiga, mempersatukan mereka dengan sikap persaudaraan dan kasih sayang. Keempat, menegakkan keadilan, kesejahteraan dan tolong-menolong. Kelima, menegakkan kepemimpinan yang mengabdi kepada kepentingan umat, mencintai dan dicintai umat. Keenam, menata masyarakat dengan hukum yang tidak berat sebelah. Ketujuh, menegakkan martabat manusia yang mulia dalam rangka membina perdamaian dan kemajuan yang bermanfaat. ${ }^{67}$ Karena itu, kegiatan politik harus memiliki sumber rujukan yang jelas kepada Allah SWT. Politik adalah salah satu kebutuhan manusia, dan segala kebutuhan manusia telah ditentukan pola dan normanya dalam Islam. Di dalam suasana tata aturan yang sempurna yang melahirkan prinsip-prinsip yang tinggi dianut oleh masyarakat

\footnotetext{
${ }^{66}$ Syukir, Dasar-dasar Strategi Dakwah, 163.

${ }^{67}$ Pimay, Paradigma Dakwah Humanis, 183.
} 
kesatuan dan persatuan berkembang dengan baik, timbulnya teori-teori politik. Akan tetapi, dia mewujudkan faktor-faktor asasi yang membangun daya tafkir untuk mewujudkan tafkir nazhary dan teori-teori politik. Faktor-faktor yang terpenting adalah membangun tafkir nazhary ada tiga macam, yaitu:

1. Tabiat dari tata aturan kemasyarakatan yang ditegakkan Rasulullah;

2. Mengakui prinsip kemerdekaan berfikir untuk setiap pribadi;

3. Menyerahkan urusan kemasyarakatan kepada umat sendiri dalam hal-hal yang berhubungan dengan rincian tata aturan dan cara-cara pelaksanaannya serta membatasi sebagian sifat-sifat yang protokoler.

Politik harus berjalan di atas landasan moralitas dan mengindahkan etika politik. Cara berpolitik yang melanggar akhlak mulia akan menimbulkan benih-benih nafsu atau mengakibatkan kontra. Oleh karena itu, partai politik yang mengetengahkan sikapnya dan memperdengarkan suaranya berarti telah menjalankan tugasnya untuk mendidik rakyat dalam politik dan menumbuhkan kehidupan demokrasi yang sehat. ${ }^{68}$ Jika itu semua dilakukan dengan niat, maka termasuk ibadah. Sebagimana dijelaskan oleh Allah dalam Surat al-Maidah ([5]: 8) sebagai berikut.

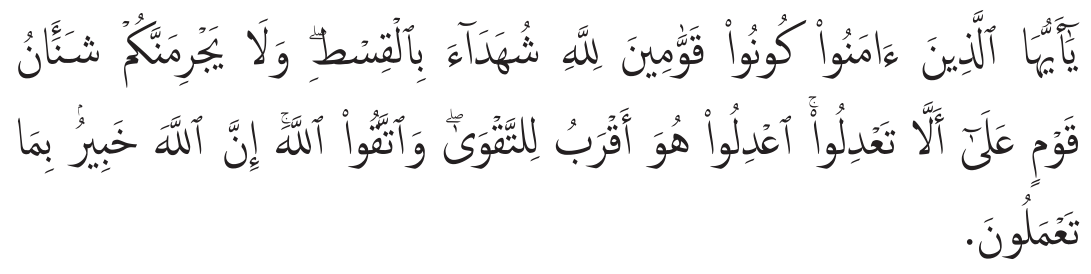

Hai orang-orang yang beriman hendaklah kamu jadi orang-orang yang selalu menegakkan (kebenaran) Karena Allah, menjadi saksi dengan adil. Dan janganlah sekali-kali kebencianmu terhadap sesuatu kaum, mendorong kamu untuk berlaku tidak adil. berlaku adillah, karena adil itu lebih dekat kepada takwa dan bertakwalah

\footnotetext{
${ }^{68}$ Ibid., 185.
} 
kepada Allah. Sesungguhnya Allah Maha mengetahui apa yang kamu kerjakan. ${ }^{69}$

Dalam Islam, setiap Muslim adalah juru dakwah yang mengemban tugas untuk menjadi teladan moral di tengah masyarakat. Dakwah akan efektif dan membuahkan hasil yang maksimal manakala juru dakwah bisa mewujudkan satunya kata dengan tindakan, akan membuat masyarakat enggan untuk mengikutinya. Untuk itu, kata kuncinya dari keberhasilan dakwah adalah keteladanan. ${ }^{70}$ Membicarakan keteladanan dakwah dengan perilaku elit politik saat ini tampaknya menjadi suatu kajian, dalam teori dakwah. Hamzah Yaqub menyebutkan ada tiga cara menyampaikan dakwah di tengah masyarakat. Pertama, dakwah lewat lisan yang dilakukan dengan ceramah-ceramah; kedua, dakwah lewat tulisan yang dengan keahlian menulis di surat kabar, majalah, dan buku; ketiga, dakwah bi al-hal (perbuatan nyata) yang menuntut adanya keteladanan.

Umat Islam dibebani tanggung jawab kemanusiaan terhadap seluruh umat manusia dan melindungi orang-orang yang beriman dari bencana yang memaksa mereka untuk konvensi agama dengan kekuatan. Kewajiban selanjutnya adalah mempertahankan kemerdekaan berdakwah dan menghapuskan setiap kekuatan zalim yang merintangi umat manusia menerima dakwah Islam. ${ }^{71}$ Islam tersebut dimaksudkan untuk menyelamatkan manusia dari kezaliman dan angkara murka di muka bumi.

Dalam mengemban misi dakwah menarik orang untuk memeluk agama Islam, hendaknya dilakukan dengan lemah lembut dan mau'idhah hasanah. Hal ini dilakukan untuk menetapkan kebebasan berdakwah. Islam sama sekali tidak pernah memaksa seseorang, supaya memeluknya,

${ }^{69}$ Depag RI, Al-Qur'an, 78.

${ }^{70}$ Hamdan Daulay, Dakwah di Tengah Persoalan Budaya dan Politik (Yogyakarta: PT. Kurnia Kalam Semesta, 2001), 79.

${ }^{71}$ Agus Wahyu Triatmo, et.al., Dakwah Islam antara Normatif dan Kontekstual (Fakultas Dakwah IAIN Walisongo Semarang, 2001), 166. 
sepeti ditegaskan dalam firman-Nya, "Tiada paksaan dalam agama; jalan yang benar telah jelas berbeda dari jalan yang sesat." 72

Keterkaitan para kiai dengan perkembangan bangsa dan negara bisa dilacak sejak kedatangan Islam di Indonesia sebagaimana dikemukakan oleh Dhofier. ${ }^{73}$ Sejak Islam menjadi agama resmi orang Jawa para penguasa harus berkompetisi dengan pembawa panji-panji Islam atau kiai dalam bentuk hierarki kekuasaan yang lebih rumit. Sebab, para kiai yang sepanjang hidupnya memimpin aktivitas kehidupan keagamaan masyarakat juga telah memeroleh pengaruh politik. Dalam konteks yang sama, Moertono ${ }^{74}$ menyatakan bahwa perebutan pengaruh antara penguasa dan para kiai biasanya selalu dimenangkan oleh pihak penguasa. Akan tetapi, tarik-menarik pengaruh tersebut tidak pernah padam dan tetap berlangsung sampai sekarang, dan para kiai tetap memainkan peran politik yang sangat menentukan.

\section{Penutup}

Dalam Sirah an-Nabawiyah tergambar dengan jelas bahwa dakwah yang tidak ditopang dengan otoritas politik tidak dapat berjalan secara efektif. Pada awal dakwah Islam di Makkah, Nabi Muhammad harus menelan pil pahit kegagalan akibat perlakuan keras dari kafir Quraisy. Sedangkan pada masa sesudahnya, seiring diakuinya sebagai kepala pemerintahan masyarakat Madinah, Nabi Muhammad menuai sukses besar dalam waktu yang tidak terlalu lama. Inilah pelajaran berharga bagi kaum formalistik jika ingin berhasil mendakwahkan Islam.

Dari situ dapat dilihat, bahwa arus substantivistik yang lebih menekankan tuntutan manifestasi substansial nilai-nilai Islam dalam aktivitas politik, bukan sekadar manifestasinya yang formal, baik dalam ide maupun kelembagaan. Bagi pendukung orientasi ini, yang lebih penting adalah eksistensi instrinsik ajaran-ajaran Islam dalam arena politik, dan untuk

\footnotetext{
72 Triatmo, et.al., Dakwah Islam, 169.

${ }^{73}$ Dhofier, Tradisi Pesantren, 58.

${ }^{74}$ Ibid., 35.
} 
mendorong Islamisasi perlu dilakukan kulturalisasi, yaitu penyiapan landasan budaya. Ini memberikan alasan mendasar bagi kaum substantivis, bahwa dalam perspektif sejarah, kulturalisasi telah memasuki persaingan antara kekuatan-kekuatan budaya yang beragam, dan Islam hanya salah satu di antaranya. Agar Islam memenangkan kompetisi ini, Islamisasi harus mengambil bentuk kulturalisasi, bukan politisasi; gerakan-gerakan Islam harus menjadi gerakan budaya dari pada gerakan politik. ${ }^{75}$

Belum cukup dua tahun hijrah ke Madinah, Nabi Muhammad mengumumkan satu piagam yang mengatur kehidupan dan hubungan antara komunitas-komunitas yang majemuk di Madinah. Dengan demikian, secara politis, Nabi Muhammad diakui sebagai pemimpin negara oleh warga Madinah dan memiliki hak untuk membuat regulasi yang dapat mengatur kehidupan warganya. Dengan posisi ini sangat menguntungkan dakwah Islam yang dilakukan Nabi. ${ }^{76}$

Pada waktu itu, Madinah tidak hanya dihuni oleh umat Islam, atau komunitas yang menolong nabi yang dikenal dengan kaum Anshar, bukan pula hanya dihuni oleh sahabat nabi yang berasal dari Makah yang disebut kaum Muhajirin. Akan tetapi, Madinah juga dihuni oleh golongan lain dan juga umat dari agama lain, seperti Yahudi, Nasrani, dan bahkan mereka yang masih menyembah berhala (musyrikin), serta mereka yang memiliki kepercayaan lainnya, seperti kaum penyembah api (Majusi). Mereka ini (penduduk Madinah disatukan oleh nabi bukan dengan memakai sentimen agama. Akan tetapi, mereka disatukan dengan sentimen kepemilikan bersama, yakni bagaimana mempertahankan Madinah dari segenap ancaman yang datang dari luar, baik berupa serangan atau ancaman apapun. ${ }^{77}$

\footnotetext{
${ }^{75}$ Abu Rohmad, "Eksperimentasi Politik Dakwah Islam: Studi Analisis Strategi Dakwah Partai Kebangkitan Bangsa," Makalah, Tidak Dipublikasikan.

${ }^{76}$ Munawir Sjadzali, Islam dan Tata Negara: Ajaran, Sejarah dan Pemikiran (Jakarta: UIP, 1993), 9-16.

${ }^{77}$ Ali Maschan Moesa, Nasionalisme Kiai: Konstruksi Sosial Berbasis Agama (Yogyakarta: LKiS, 2007), 241.
} 
Piagam Madinah itu terdiri dari 47 pasal yang menandakan berdirinya Negara yang pluralistik dan menunjukkan bahwa nabi tidak mendirikan negara agama. Secara rinci, isi pokok piagam tersebut adalah (1) mempersatukan seluruh umat Islam dari berbagai suku menjadi satu ikatan; (2) menghidupkan semangat gotong-royong, hidup berdampingan, saling menjamin keselamatan di antara warga Madinah; (3) menetapkan bahwa setiap warga masyarakat memiliki kewajiban untuk mengangkat senjata untuk melawan jika diserang orang luar Madinah; dan (4) menjamin persamaan dan kebebasan bagi kaum Yahudi, Nasrani, Musyrikin (penyembah berhala), dan kaum Majusi (penyembah api), untuk mempertahankan kepercayaan dan keimanannya. ${ }^{78}$

Dalam pembentukan Piagam Madinah, ternyata ada semangat untuk tidak hanya melindungi umat Islam, tetapi juga menyelamatkan Madinah sebagai tempat dimana umat Islam dan pemeluk agama lainnya hidup secara koeksistensi. Semangat tersebut tampak dari adanya keinginan untuk menjaga dan menyelamatkan Madinah dari berbagai serangan orang luar, terutama kaum Quraisy Makkah. Oleh karena itu, realitas sosial yang mengemuka di dalam Piagam Madinah adalah pengakuan adanya pluralitas di dalam kehidupan berbangsa dan bermasyarakat, yakni adanya variasi agama, keyakinan, suku, kabilah, dan latar belakang lainnya. ${ }^{79}$ Jelaslah bahwa tujuan Nabi Muhammad, sejak Piagam Madinah dan fase paling awal dakwah di Madinah adalah untuk mengubah konfederasi kesukuan menjadi sebuah masyarakat baru yang dikendalikan oleh ajaran tentang moral. ${ }^{80}$ Piagam Madinah tidak sekadar menempatkan Nabi Muhammad Saw. sebagai pemimpin agama, tetapi juga pemimpin Negara.

\footnotetext{
${ }^{78}$ Munawir Sadzali, Islam dan Tata Negara (Jakarta: UI Press, 1995), 84.

${ }^{79}$ Moesa, Nasionalisme Kiai, 243.

${ }^{80}$ Antoni Black, Pemikiran Politik Islam; Dari Masa Nabi Hingga Masa Kini (Jakarta: PT Serambi Ilmu Semesta, 2001), 37.
} 


\section{DAFTAR PUSTAKA}

Abdalla, Ulil Abshar. "Pesantren dan Budaya Tulis." Ulil Abshar Abdalla. Membakar Rumah Tuhan: Agama Privat dan Publik. Cet. II. Bandung: Rosda, 2000.

Abdullah, Dzikron. Metodologi Dakwah. Semarang: Fakultas Dakwah IAIN Walisongo Semarang, 1989.

Ahmad, Amrullah. Dakwah Islam dan Perubahan Sosial. Yogyakarta: Prima Duta, 1983.

Arifin, M. Psikologi Dakwah: Suatu Pengantar Studi. Jakarta: Bulan Bintang, 1977.

al-Bukhari, Imam. Shahih Bukhari. Istambul: Darul Fikr.

Anas, Ahmad. Paradigma Dakwah Kontemporer: Aplikasi Teoritis dan Praktis Solusi Problematika Kekinian. Semarang: PT. Pustaka Rizki Putra, 2006.

Anwar, H. Fuad. Melawan Gus Dur. Yogyakarta: Pustaka Tokoh Bangsa, 2004.

Anshari, Endang Saifudin. Kuliah al-Islam. Jakarta: Rajawali, 1992.

Arifin, M. Psikologi Da'wah: Suatu Pengantar Studi. Jakarta: Bulan Bintang, 1977.

Baidan, Nashruddin. Perkembangan Tafsir al-Qur'an di Indonesia. Jakarta: Tiga Serangkai, 2003.

al-Bantani, Imam Nawawi. Hadits Arbain an-Nawawiyah. Cet. IV. Surabaya: Media Insani Press, 2003.

Black, Antoni. Pemikiran Politik Islam: Dari Masa Nabi Hingga Masa Kini. Jakarta: PT Serambi Ilmu Semesta. 2001.

Cahyono, Cheppy Hari. Ilmu Politik dan Perspektifnya. Yogyakarta: Tiara Wacana, 1991.

Daulay, Hamdan. Dakwah di tengah Persoalan Budaya dan Politik. Yogya- 
karta: PT. Kurnia Kalam Semesta, 2001.

Dhofier, Zamakhsari. Tradisi Pesantren: Studi Tentang Pandangan Hidup Kyai. Jakarta: LP3ES, 1982.

al-Ghazali, Abu Hamid. Amar Ma'ruf Nahi Munkar. terj. Muhammad Bagir. Bandung: Penerbit Karisma, 2003.

Hasan, Muhammad Kamal. Modernisasi Indonesia: Respons Cendekiawan Muslim. Surabaya: Bina Ilmu, 1987.

Hasbullah. Dinamika Sistem Pendidikan Pesantren. Jakarta: PT Raja Grafindo Persada, 1999.

Hasjmy, A. Dustur Da'wah Menurut al-Qur'an. Jakarta: Bulan Bintang, 1974.

Hasjmy, A. et.al.Pengantar Ilmu Dakwah. Proyek Pembinaan Perguruan Tinggi Agama IAIN Jamiah Ar-Raniry Darussalam, 1984/1985.

Huda, Ahmad Zaenal. Mutiara Pesantren: Perjalanan Khidmah KH. Bisri Mustofa. Yogyakarta: LKIS. 2005.

Ja’qub, Hamzah. Publistik Islam dan Dakwah. Bandung: CV. Diponegoro, 1973.

Kuntowijoyo. Identitas Politik Umat Islam. Bandung: Mizan, 1997.

Kurnia, MR. Al-Jamaah, Tafarruq dan Ikhtilaf. Bogor: Al-Azhar Press, 2002.

Liddle, R. William. Pemilu-pemilu Orde Baru: Pasang Surut Kekuasaan Politik. Jakarta: LP3ES, 1992.

Ma’arif, Ahmad Syaf'i. Membumikan al-Qur'an. Yogyakarta: Pustaka Pelajar, 1995.

Madjid, Nurcholis. Bilik-Bilik Pesantren: Sebuah Potret Perjalanan. Jakarta: Paramadina, 1997. . Islam Keindonesiaan dan Kemodernan. Jakarta: Paramadina, 1993.

Mas'ud, Abdurrahman, et.al. Dinamika Pesantren dan Madrasah. Semarang: Fakultas Tarbiyah IAIN Walisongo Semarang dengan 
Pustaka Pelajar, 2002.

Misrawi, Zuhairi. Hadratussyaikh Hasyim Asyari: Moderasi, Keumatan, dan Kebangsaan. Jakarta: PT. Kompas Media Nusantara, 2010.

Moesa, Ali Maschan. Nasionalisme Kiai: Konstruksi Sosial Berbasis Agama. Yogyakarta: LKiS, 2007.

Muis, A. Komunikasi Islam. Bandung: PT. Remaja Rosdakarya, 2001.

Mulkhan, Abdul Munir. Kiai Ahmad Dahlan: Jejak Pembaruan Sosial dan Kemanusiaan: Kado Satu Abad Muhammadiyah. Jakarta: Penerbit Buku Kompas, 2010.

Mursyid, Ahmad Murodi (ed.). Spektrum dan Garis Perjuangan Pelajar Nahdhatul Ulama: Hasil Kongres XVI Ikatan Pelajar Nahdlatul Ulama 19-24 Juni 2009. Jakarta: Sekjend PP IPNU, 2010.

Muslim, Imam. Shaheh Muslim. Qahira: Maktabah Masyhad al-Husainy.

Nata, Abuddin. Metodologi Studi Islam. Jakarta: Raja Grafindo Persada, 1998.

Natsir, Mohammad. Fiqhud Da'wah. Jakarta: Media Da’wah, 2000

Pimay, Awaludin. Paradigma Dakwah Humanis: Strategi dan Metode Dakwah Prof. KH. Saifudin Zuhri. Semarang: Rasail, 2005.

al-Qardhawi, Yusuf. Kebangkitan Gerakan Islam: Dari Masa Transisi Menuju Kematangan. Jakarta: Pustaka al-Kautsar, 2003.

Raharjo, M. Dawam (ed.). Pesantren dan Pembaharuan. Jakarta: LP3ES, 1988.

Rahmat, Jalaludin, et.al. Hegemoni Budaya. Yogyakarta: Yayasan Bentang Budaya, 1997.

Rais, Amien. Cakrawala Islam. Jakarta: Mizan, 1987.

Ridwan, Nur Khalik. NU \& Bangsa 1914-2010: Pergulatan Politik \& Kekuasaan. Yogyakarta: ar-Ruzz Media, 2010.

Rudy, Teuku May. Pengantar Ilmu Politik, Wawasan Pemikiran dan Kegunaanya. Bandung: PT. Eresco, 1993. 
Sadzali, Munawir. Islam dan Tata Negara. Jakarta: UI Press, 1995.

ash-Shiddiqi, Tengku Muhammad Hasbi. Islam dan Politik Bernegara. Semarang: PT. Pustaka Rizki Putra, 2002.

Saidi, Anas. "Makalah-makalah Metodologi Penelitian." Makalah. Tidak Diterbitkan.

Saifudin, Azwar. Metode Penelitian. Yogyakarta: Pustaka Pelajar, 1998.

Sjadzali, Munawir. Islam dan Tata Negara: Ajaran, Sejarah dan Pemikiran. Jakarta: UIP, 1993.

Smith, Donald Eugene. Agama dan Modernisasi Politik: Suatu Kajian Analitis. Jakarta: Rajawali Press, 1985.

Sulthon, Muhammad. Desain Ilmu Dakwah. Yogyakarta: Pustaka Pelajar, 2003.

Suprayogo, Imam Tobroni. Metodologipenelitian Sosial-Agama. Bandung: Remaja Rosdakarya, 2001.

Surbakti, Ramlan. Memahami Ilmu Politik. Jakarta: Gramedia, 1992.

Syukir, Asmuni. Dasar-dasar Strategi Dakwah Islam. Surabaya: al-Ikhlas, 1983.

Tasmara, Totok. Komunikasi Dakwah. Jakarta: Radar Jaya, 1987.

Tim Penulis Depag RI. Al-Quran al-Karim dan Terjemahnya. Bandung: CV. Diponegoro, 2004.

Triatmo, Agus Wahyu, et.al. Dakwah Islam Antara Normatif dan Kontektual. Semarang: Fakultas Dakwah IAIN Walisongo, 2001.

Turmudi, Endang. Perselingkuhan Kiai dan Kekuasaan. Yogyakarta: PT. LKiS Pelangi Aksara, 2004.

Wahid, Abdurrahman. "Politik Sebagai Moral, Bukan Institusi." Majalah Prisma, No. 5, 1995.

Winardi. Pengantar Ilmu Politik. Jakarta: Mandar Maju, 1994.

Yunus, Mahmud. Kamus Arab Indonesia. Jakarta: Yayasan Penterjemah 
64 | TASAMUH, Volume 10, Nomor 1, April 2018

al-Qur'an, 2007.

Zen, Fathurin. NU Politik: Analisis Wacana Media. Yogyakarta: LKiS, 2004.

Ziemek, Manfred. Pesantren dalam Perubahan Sosial. Jakarta: P3M, 1986. 